\title{
West African Manatee Trichechus senegalensis (LINK, 1795) in the Estuary of the Congo River (Democratic Republic of the Congo): Review and Update
}

Laudisoit $A^{1-4^{*}}$, Collet $\mathbf{M}^{5,6}$, Muyaya $\mathbf{B}^{5}$, Mauwa $\mathbf{C}^{7}$, Ntadi $\mathbf{S}^{7}$, Wendelen $\mathbf{W}^{8}$, Guiet $\mathbf{A}^{5}$, Helsen $\mathbf{P}^{1,9}$, Baudouin $\mathbf{M}^{7,10}$, Leirs $\mathbf{H}^{1}$, Vanhoutte $\mathbf{N}^{1}$, Micha $\mathrm{JC}^{7,11}$ and Verheyen $\mathrm{E}^{1,10}$

${ }^{1}$ Evolutionary Ecology Group, University of Antwerp, Antwerp, Belgium

${ }^{2}$ Center for International Forestry Research (CIFOR), Situ Gede, Sindang Barang Bogor (Barat) 16115, Indonesia

${ }^{3}$ Institute of Integrative Biology, University of Liverpool, UK

${ }^{4}$ Royal Belgian Institute of Natural Sciences, OD Taxonomy and Phylogeny, 1000 Brussels, Belgium

${ }^{5}$ Marine Mangrove Park, Moanda, Democratic Republic of the Congo

${ }^{6}$ Snake Venom Extraction Centre, University of Kinshasa, Democratic Republic of the Congo

${ }^{7}$ Postgraduate Regional School of Planning and Integrated Management of Tropical Forests and Territories (ERAIFT), University of Kinshasa, Kinshasa, Democratic Republic of Congo

${ }^{8}$ Royal Museum for Central Africa, 3080 Tervuren, Belgium

${ }^{9}$ Royal Zoological Society of Antwerp (RZSA), Centre for Research and Conservation, 2018 Antwerp, Belgium

${ }^{10}$ University of Liège/Gembloux, Rural Economy and Development Group, 5030 Gembloux, Belgium

${ }^{11}$ University of Namur, 5000 Namur, Belgium

\begin{abstract}
The West African manatee Trichechus senegalensis (LINK, 1795) is the least studied Sirenian species, with both old and fragmentary literature on the population in the Congo River estuary. In the Democratic Republic of the Congo, $T$. senegalensis occurs up to $60 \mathrm{~km}$ upstream around Boma town, a zone under partial protection of the Marine Mangrove Park. In order to develop efficient conservation actions, there is an urgent need to revise the state of knowledge on the species in the Congolese part of its distribution range. This paper reviews the current status and distribution of $T$. senegalensis populations in the Congo River estuary based on geolocated observations $(\mathrm{N}=33)$, and provides a summary of local communities' knowledge, attitude and practices of the manatees 'ecosystem services (e.g.: river dredging, touristic potential). The reported potential threats-poaching, habitat loss, risk of genetic drift-show that the $T$. senegalensis population of the Congo River estuary is in danger and that its survival requires specific conservation measures.
\end{abstract}

Keywords: Manatee; Trichechus senegalensis; conservation; Democratic Republic of the Congo; Mangrove

\section{Introduction}

\section{Sirenians and Trichechus senegalensis: generalities}

Sirenians, or sea cows, are an order of fully aquatic, herbivorous mammals that inhabit swamps, rivers, estuaries, marine wetlands, and coastal marine waters. All four extant species are threatened with extinction through habitat loss and other negative impacts related to human population growth and coastal development. A fifth species, the Steller's sea cow (Hydrodamalis gigas ZIMMERMANN, 1780), became extinct in the $18^{\text {th }}$ century. The four remaining species: Dugong dugon (MÜLLER, 1776), Trichechus senegalensis (LINK, 1795), Trichechus manatus (LINNAEUS, 1758) and T. inunguis (NATTERER, 1883) are protected by local and international laws. The West African manatee, T. senegalensis LINK, 1795 is the most threatened and the least studied among these species. It was classified as 'vulnerable' by the International Union for Conservation of Nature (IUCN) since 1986, and since 2013 it has been added to Appendix I of the Convention on the International Trade of Endangered Species (CITES) by the $16^{\text {th }}$ Convention of the Parties (COP).

West African manatees occur along the Atlantic coast of 22 African countries, reaching from the Senegal River to the Cuanza River in Angola. They have been recorded as far as 2,000 km inland; from the Niger River from Koulikoro to Gao; in Lake Debo in Mali; and in Lakes Léré and Tréné in Chad (Figure 1) [1]. This species appears to occur in marine, brackish as well as freshwater systems, represented by rivers, channels and lagoons [2].

So far, there is no reliable information on the true extent of the distribution range of this species, both on the African continent, as well as in the Atlantic Ocean. In absence of reliable information for the West African manatee populations, information on habitat preferences and population densities of the well studied Florida manatee populations [3-5] have been used to infer that there may be fewer than 10,000 manatees in West Africa [6].

The wide distribution of $T$. senegalensis is in sharp contrast with the amount of published information about this species' biology, dynamics, distribution, and status [7]. This could be explained in part by the manatees' elusive nature and their preference for turbid, sediment-rich waters which are an obvious obstacle for direct or indirect observations in the wild. Although live West African manatees are displayed in some Asiatic zoos or aquaria, there are virtually no published records concerning their behaviour in captivity. The CITES database reports that 15 official certificates for importing 44 wild caught live manatees in various countries have been granted between 1975 and 2013. China, Japan, the Republic of Korea and Taiwan are the only importers

*Corresponding author: Anne Laudisoit, Evolutionary Ecology Group, University of Antwerp, Universiteitsplein 1, 2610 Antwerp, Belgium, Tel: 032653469; Fax: 032653474; E-mail: Anne.laudisoit@liverpool.ac.uk

Received November 27, 2016; Accepted January 25, 2017; Published January 31, 2017

Citation: Laudisoit A, Collet M, Muyaya B, Mauwa C, Ntadi S, et al. (2017) West African Manatee Trichechus senegalensis (LINK, 1795) in the Estuary of the Congo River (Democratic Republic of the Congo): Review and Update. J Biodivers Endanger Species 5: 181. doi: 10.4172/2332-2543.1000181

Copyright: (c) 2017 Laudisoit A et al. This is an open-access article distributed under the terms of the Creative Commons Attribution License, which permits unrestricted use, distribution, and reproduction in any medium, provided the original author and source are credited. 
Citation: Laudisoit A, Collet M, Muyaya B, Mauwa C, Ntadi S, et al. (2017) West African Manatee Trichechus senegalensis (LINK, 1795) in the Estuary of the Congo River (Democratic Republic of the Congo): Review and Update. J Biodivers Endanger Species 5: 181. doi: 10.4172/23322543.1000181

Page 2 of 11

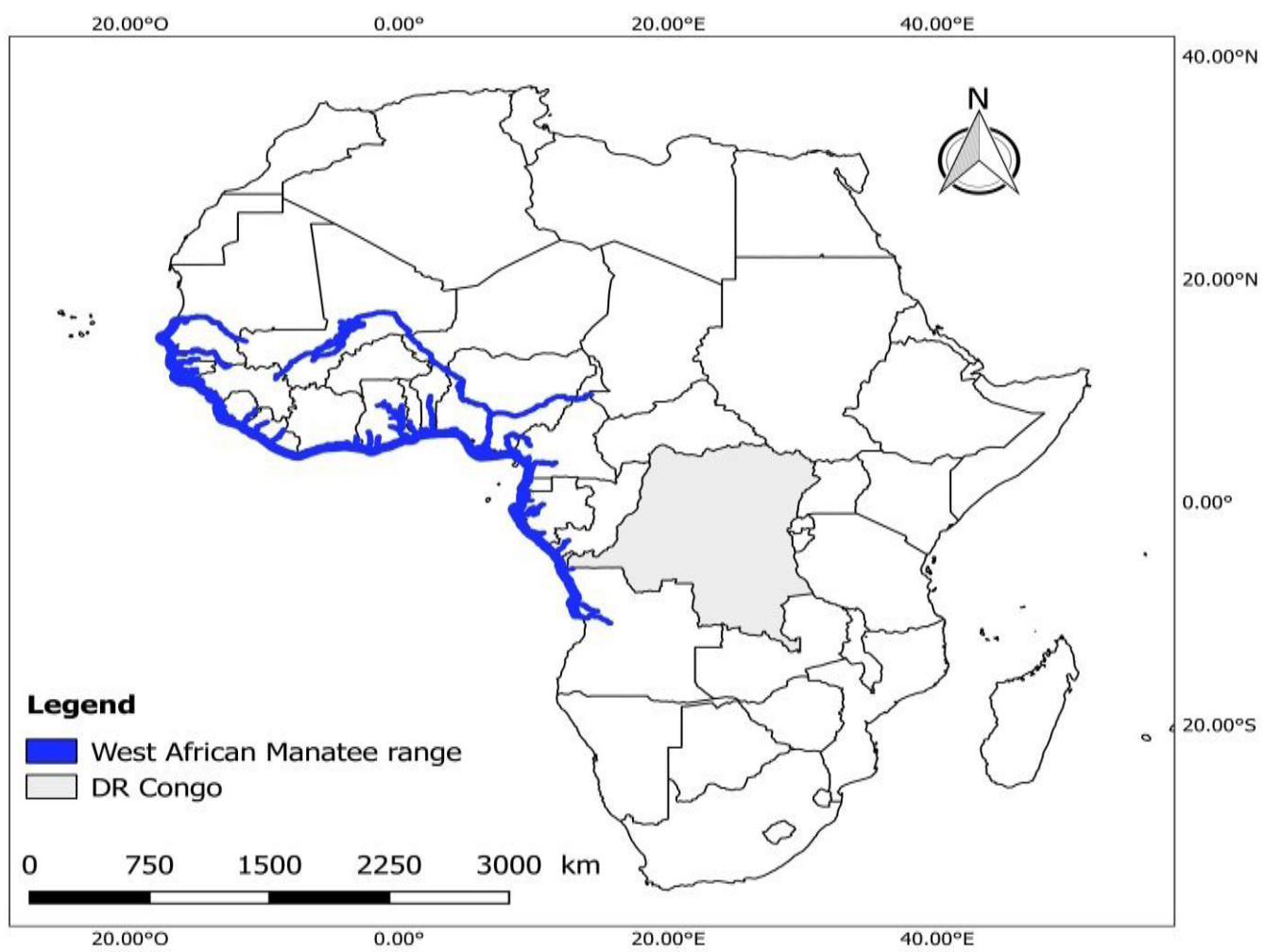

Figure 1: Map showing the distribution range of the West African manatee and the location of the Democratic Republic of the Congo [1]

while Guinea, Guinea Bissau, Cameroon and Ivory Coast are the only exporters. In Nigeria, wild-caught manatees are displayed in local zoos and in Guinea-Bissau manatees are offered for sale on the internet [8]. There was a sharp increase in the export of West African manatees between 2008 and 2013, from Guinea Bissau and Cameroon to China and a stop to further sales in 2013 when it was assigned to the CITES Annex 1. Although in the past, manatees originating from the Congo River have been on display in zoos, to our knowledge no such animals are currently part of any zoo collection.

\section{Threats and potential effects of stochastic processes in reduced manatee populations}

Although manatees are legally protected in all the countries in which they occur, they are routinely killed for human consumption, or used as ingredients in traditional medicinal products throughout their distribution range [9]. Summarized the manatee body parts used and associated beliefs in Africa, but no such data exist for the Democratic Republic of the Congo (DRC) [10].

West African manatees have no natural enemies except for humans, sharks and crocodiles [2]. They are often trapped with nets, large box traps, drop traps using harpoons and snaglines [11,12]. While the decline of their populations is often linked to hunting and the incidental capture during fishing, human induced habitat changes (e.g. mangrove cutting and dam building) might be another contributing factor $[13,14]$

Some endo- and ecto- parasites are known to infest T. senegalensis [15], but little is known on their impact on manatee health. While Poxvirus and Brucella spp. are common in marine mammals [16], no reports or investigations on infectious diseases could be found for T. senegalensis.
The genetic threat due to reduced populations size should be addressed as it can provide information on population size both locally and across its range. Recent genetic analyses for a series of West African samples suggested high haplotype diversity, but low nucleotide diversity, which may indicate a recent demographic expansion after a period characterized by a low effective population size [1]. The latter analysis did not include genetic information obtained from specimens representing manatee populations in the DRC.

\section{West African manatee behaviour in the wild and in captivity}

Anecdotal information suggests that $T$. senegalensis migrates in response to water temperature drop, and water level increase [17]. Indeed, T. senegalensis appears to prefer areas that provide access to deep pools or connecting lakes that can serve as refuges during the dry season in which salinity change and food availability vary seasonally. For instance in Senegal, manatee movements are often seasonal (usually at the start and end of each rainy season) in response to changing water levels, the availability of preferred vegetation, changing water salinity, and the approach of the breeding season $[18,10]$. Manatees are herbivores that spend 6-8 h per day feeding. They mainly eat floating vegetation and grass such as Eichhornia crassipes SOLMS, Echinochloa pyramidalis HITCHC and CHASE, Vossia sp. WALL, and GRIFF, Paspalum vaginatum SW., Cyperus sp. L. or Typha sp. L. and immerged mangrove propagules $[19,20]$.

In comparison to other mammals, their metabolic rate and body temperature $\left(36^{\circ} \mathrm{C}\right)$ is relatively low, and it is influenced by ambient temperature [21]. The distribution range of this species appears to be limited to water bodies with temperatures between $18^{\circ} \mathrm{C}$ and $27^{\circ} \mathrm{C}$ $[22,23]$. During the daytime, manatees usually rest in shallow (1-2 $\mathrm{m})$ water, surfacing to breathe approximately every $3 \mathrm{~min}$ [23]. In 
1968, similar diving times were recorded for a captive Congo River $T$. senegalensis male in the Antwerp Zoo (Belgium) with average diving time of $2.7 \mathrm{~min}$ (maximal value recorded=3.3 min) during periods of inactivity and $1.8 \mathrm{~min}$ during daily activities. Their limited temperature tolerance and their need to breathe air may explain their movement patterns and why this species does not occur in sections of rivers that are deep, or where the water flow is very strong.

The reproductive biology and social structure of $T$. senegalensis is poorly known. Females presumably start breeding at the age of 7 years and have one calf (rarely twins) after a gestation period of 12-14 months. Whether specific breeding sites exist is unclear, but literature and West African fishermen report encounters with females and calves in small, calm and shallow tributaries, especially during the rainy season $[10]$

\section{West African manatee genetic diversity}

Anecdotal evidence suggests that $T$. senegalensis may contain two subspecies. In the DRC, Derscheid [24] suggested the existence of a darker coloured coastal (T. senegalensis) occurs in the salty waters, and a lighter inland form (T. senegalensis vogellii) living in fresh water, possibly related to the Chadian manatee populations. While recent population genetic studies on West African manatees detected considerable genetic diversity (haplotype and microsatellite diversity), so far there seems to be no genetic basis for the existence of the presumed subspecies [3,25].

\section{West African manatee distribution in the Democratic Republic of the Congo}

In the Democratic Republic of the Congo, the distribution range of $T$. senegalensis is situated between the mouth of the Congo River around Moanda and Banana to $60 \mathrm{~km}$ upstream around Boma town [24]. Interestingly, there are no reports of their presence off the coast of DRC in the Atlantic Ocean. Between the mouth of the Congo River and the Lukunga River near Boma, the species benefits from some protection by the Marine Mangrove National Park rangers that regularly carry our surveillance patrols in this area.

Here are summarized the state of the knowledge on T. senegalensis populations in the Democratic Republic of the Congo and provides new observations on the manatee population occurring in the Congo River estuary. More specifically, we aim to:

Review the old literature published on-line or in archives;

$>$ Provide updated information concerning the current distribution of extant $T$. senegalensis populations in the Congo River estuary;

> Position the Congo River T. senegalensis population in the Sirenidae evolutionary history using mitochondrial DNA sequences;

$>$ Report on the sensitivity of local fishermen towards the endangered status of manatees;

Provide perspectives for the conservation of the manatee populations in this region.

\section{Material and Methods}

\section{Review of Trichechus senegalensis literature from the Democratic Republic of the Congo}

The literature review was based on a search in the global server
Google, and the scientific databases PubMed and Google Scholar from 1966 through $31^{\text {st }}$ August 2015. Searches using the words "siren*, Congo, Congo Kinshasa, Congo River, Zaire, Belgian Congo, manatee, and T. senegalensis" targeted titles, abstracts, keywords and full text both with the terms in French and English. In addition, we exploited all the on-line issues of the specialized Sirenews database (April 1984-October 2014) and all papers relevant to the current study trying to focus on $T$. senegalensis morphology, biology, distribution and behaviour with a direct link towards (future) threats of this species. We also consulted the library of the Royal Museum for Central Africa and internal collection databases for more information on the skeleton and skull collections. Finally, we gathered information on the former ex-situ population from internal reports and veterinarian archives of the Royal Zoological Society of Antwerp (the Antwerp Zoo, Belgium).

\section{Study site description and the distribution range of Congolese Trichechus senegalensis populations}

The Marine Mangrove Park (MMP) is the only coastal RAMSAR site within the boundaries of the DRC and a protected area located at the mouth of the Congo River in the former province of Bas-Congo (now Kongo Central). The park covers 76800 ha $\left(768 \mathrm{~km}^{2}\right)$, of which $20 \%$ are located in the Atlantic Ocean. In 2011, the new direction of the MMP drew updated conservation guidelines with a double focus:

$>$ Reduce the pressure on the mangrove forest.

$>$ Intensify the anti-poaching activities targeting resident marine turtles (5 spawning species) and manatees that are the MMP's major flagship species.

The MMP ecosystems is dominated by swamps, raffia palm forests, seasonally flooded forests, mangrove forests (dominated inland by Rhizophora racemosa G.MEY.), and including savannas. The monthly temperature ranges between $22^{\circ}$ and $24^{\circ} \mathrm{C}$ while the monthly relative humidity $(77-81 \%)$ is relatively high as is the annual rainfall (around $772 \mathrm{~mm}$ ). The rainy and dry seasons typically respectively last from October to May and between June and September. The altitudinal profile of the MMP ranges between 0-110 $\mathrm{m}$ [26].

\section{Mapping of the marine mangrove park}

The manatee observations and study area were mapped by classifying and clustering 5 classes of a Landsat scene (landuse mapping and landscape classification) validated by ground trothing observations (classification). The visible, near infrared VNIR and short wave infrared SWIR channels of the Landsat LO8 full scene from 2015 (LC81760602015189LGN00 acquired on 2015-07-08) were stacked and clipped on the study area from the Atlantic coast to Boma town. For selected areas, these data were validated on the basis of validation surveys on the ground using a handheld Garmin GPS MAP 78. A supervised classification (maximum likelihood algorithm) was performed with ENVI 5.0. The obtained result was ultimately enhanced with a transparent true colors composite background image in order to sharpen the limits of the classes with QGIS (QGIS development team, 2016) and produce the Figure 2.

\section{Interviews}

Between October and December 2014 and in May 2015, we gathered data on the species' presence in the Congo River estuary and local communities' knowledge about manatees by individual $(n=23)$ and group $(n=11)$ interviews as well as information gathered from informal discussions with local people. We developed our questionnaires starting from existing question forms used for manatees in West Africa 
Citation: Laudisoit A, Collet M, Muyaya B, Mauwa C, Ntadi S, et al. (2017) West African Manatee Trichechus senegalensis (LINK, 1795) in the Estuary of the Congo River (Democratic Republic of the Congo): Review and Update. J Biodivers Endanger Species 5: 181. doi: 10.4172/23322543.1000181

Page 4 of 11

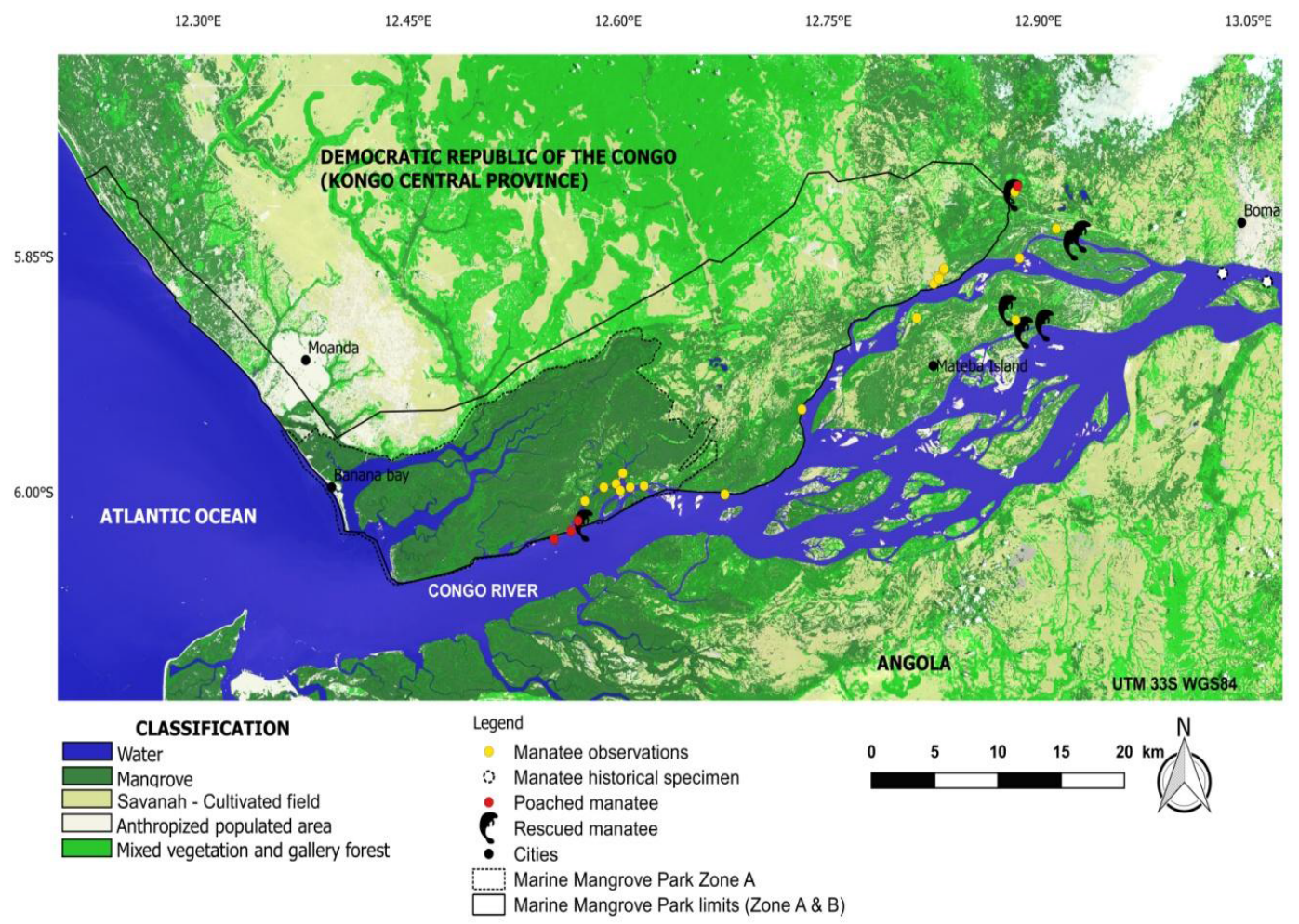

Figure 2: Study area (Congo River estuary), Trichechus senegalensis manatee specimen's report of observations, and location of live and dead animals between 2010 and 2015, and documented historical specimens (before 1970).

[10, Mauwa, 2015). The questions were tailored to address how the local population perceives various aspects of the manatee distribution, biology, hunting techniques, use, beliefs and legends, and threats with regard to manatees.

Our survey mainly targeted fishermen living in temporary and permanent settlements within the true mangrove area $(\mathrm{N}=20)$, along the Congo River towards Boma $(\mathrm{N}=8)$, along the Lukunga river on the road from Moanda to Boma $(\mathrm{N}=2)$ and in Banana (Moanda) coastal town $(\mathrm{N}=4)$. More informal discussions targeted group of fishermen whose families have been involved in fishing activities for 3 generations along the coastal line of Banana. Respondents belonged to the Woyo, Kongo and Assolongo tribes who farm, fish, and indulge in charcoal production activities in the study area.

\section{In situ surveys}

Locations where manatees were observed (sightings, poaching events, capture in fishing and specialized nets) between 2011 and 2015 were recorded using a GPS (Garmin 62S) during boat patrols. Local names of plants consumed by manatees were recorded and samples of plants photographed. During the surveys, the MMP rangers also rescued 7 manatees that got either trapped in nets or stranded in small channels and water holes of the Congo River estuary as the water level suddenly dropped at the dry season turn. Finally, fishermen handed a young specimen, which accidentally drowned in their fishing nets, to the park rangers. The geographic coordinates of these sites were also recorded with a GPS (Garmin 62S).

\section{Genetic analysis}

Skin biopsies were taken from the 7 rescued specimens and a piece of muscle was dissected from the dead specimen. All samples were stored individually in $90 \%$ ethanol and exported to Belgium. Once in the laboratory, DNA was extracted using NucleoSpin tissue kit (Machery Nagel, Düren, Germany) according to manufacturer's recommendation. A $\sim 550 \mathrm{bp}$ fragment of the mtDNA control region (D-loop) was amplified and sequenced following the procedures outlined in Vianna et al. [25]. These were sequenced in a MegaBACE 1000 (Amersham-Biosciences) using the DYEnamic ET $^{\circ}$ Dye Terminator Kit (Amersham-Biosciences). New sequence data have been deposited in GenBank and will be released after the publication of this manuscript.

\section{Phylogenetic analyses}

To infer the genealogic relationships among the Congolese manatee population and other African populations, we included sequences from: T. senegalensis from Niger, Guinea-Bissau, Ghana and Chad $(n=5$, AY963894 till AY963898) [25], Trichechus inuguis ( $\mathrm{n}=1$, AY963885) and the fossil taxon Hydrodamalis gigas ( $\mathrm{n}=1, \mathrm{KP} 134340)$, adding the Dugong ( $\mathrm{n}=1$, AY963899) as an out group. All sequences were aligned using ClustalW in Mega 6. Based on this 415 bp long final alignment, a neighbour joining (NJ) tree was constructed using 500 bootstrap replications and a $\mathrm{p}$-distance model, with pairwise gap deletion. MP trees were also inferred using a branch swapping tree-bisectionreconnection algorithm with random addition of 10 initial trees, and 500 bootstrap replicates. Finally, we determined the nucleotide substitution model using all sites and the model with the lowest BIC and AIC likelihood scores to construct Maximum Likelihood trees. The obtained ML tree (shown here) was calculated using 500 bootstrap replicates, the $\mathrm{HKY}+\mathrm{G}$ model, gaps were included and the nearest neighbour interchange (NNI) option was used as heuristic method. All tree building procedures were performed in Mega 6 . 
Citation: Laudisoit A, Collet M, Muyaya B, Mauwa C, Ntadi S, et al. (2017) West African Manatee Trichechus senegalensis (LINK, 1795) in the Estuary of the Congo River (Democratic Republic of the Congo): Review and Update. J Biodivers Endanger Species 5: 181. doi: 10.4172/23322543.1000181

Page 5 of 11

\section{Manatee morphometric measurements and identification}

Body measurements and external examination of the 7 rescued specimens and of the dead manatee were executed as described in the "Pictoral Guide for Manatee Standard Photos and Measurement" (Keith Diagne, unpublished). We have recorded the following eleven measurements:

$>$ Total straight length;

$>$ Snout-anus distance;

$>$ Snout-urogenital orifice distance;

$>$ Snout-umbilicus distance;

$>$ Flipper width;

$>$ Length and width of fluke, and axillary girth;

Girth at caudal peduncle;

$>$ Girth at anus;

Girth at umbilicus measurements.

Presence and location of scars were noted. Before being released, four of the live specimens were subcutaneously tagged with a PIT tag (Vethica, France) at the base of the right flipper. Apart from these field data, we used carcasses of the African manatees stored at the Royal Museum for Central Africa (RMCA), a collection including both direct imports from the Congo basin as well as specimens that formally (1900-1970) were displayed at the Antwerp Zoo (RZSA) (Tables 1 and 2). Apart from skins, skulls and bones, this collection also includes a complete young unweaned calf in ethanol (RMCA 31512).

\section{Compliance with Ethical Standards}

The authors declare they have no conflicts of interest. CITES certificate number 6543 has been granted in order to export manatee biopsies and is provided as supplementary material.

\section{Results and Discussion}

\section{Trichechus senegalensis status in the DR Congo: Review}

The first written mention of manatees in the former Belgian Congo dates back to 1876 but its occurrence is reported as far back as the $17^{\text {th }}$ century. The presence of the "woman-fish" in the mouth of the Congo River is later confirmed by Walckenaer in 1828 and Buffon in 1930 . Between 1870 and 1960, manatee specimens have been collected from the Bas Congo region and several live specimens were imported to Belgium. A captured specimen survived from its arrival in Antwerp zoo on $7^{\text {th }}$ October 1922 to $19^{\text {th }}$ March 1923 when it died of an acute gastroenteritis. The skull and skeleton are stored at the Royal Museum for Central Africa (RMCA) in Brussels (specimen 6063b in Table 1). In 1929, a second specimen was acquired (specimen 9583 in Table 1) but died the same year. A last specimen was acquired in 1954 and died 16 years later (specimen 35741 in Table 1). All the imported specimen that are documented originated from the Congo River estuary sensu lato namely a $60 \mathrm{~km}$ stretch of the Congo River between Boma and the Banana bay.

There are reports that document the presence of manatees in the Mbomu and Uélé, and the Kibali tributary of the Uélé River in the HautUélé district as well as in the Fwa Lake and according to IUCN, based on old literature "a local name for the species exists in the upper reaches of the Congo, so it may occur there as well" [22]. However, there is-to our knowledge-no conclusive evidence to confirm these statements. All confirmed observations or collected specimens, including all sites where T. senegalensis may be present in the Democratic Republic of the Congo are mapped in Figure 3.

\section{Current observations in the Democratic Republic of the Congo}

Between 2010 and 2015, the MMP team recorded 33 geolocalized observations of manatees (Figure 2). These observations were classified as direct sights ( $\mathrm{N}=19$, with multiple sightings in some areas), poached animals $(\mathrm{N}=2)$, reports of poached animals $(\mathrm{N}=7)$, animals stranded in

\begin{tabular}{|c|c|c|c|c|c|c|}
\hline Current location & Sp. No & Origin & Coll. & Acquisition date at location & Sex & Specimen \\
\hline RMCA $^{* *}$ & 53 & Bas Congo & Cabra & unknown & $\mathrm{M}$ & Skin \\
\hline RMCA & 110 & Bas Congo & Weyns & 1898 & $\mathrm{~F}$ & Skin \\
\hline RMCA & 111 & Bas Congo & Weyns & 1898 & M & Skin \\
\hline RMCA & 660 & Bas Congo & Cabra & unknown & $?$ & Skin \\
\hline RMCA & 661 & Bas Congo & Cabra & unknown & M & Skull/skeleton \\
\hline RMCA & 5586 & unknown & Cavens & unknown & M & skull/skeleton \\
\hline RMCA & 5587 & unknown & Cavens & unknown & M & Skull \\
\hline RMCA & 5588 & unknown & Cavens & unknown & $\mathrm{M}$ & Skull \\
\hline RMCA & 5589 & unknown & Cavens & unknown & $\mathrm{M}$ & Skull \\
\hline ANMH* $^{*}$ & & Banana & & 1915 & $\mathrm{~F}$ & Skin/skeleton/palatal pads \\
\hline RMCA & $6063 a$ & Shinka Boma & Zoo Antwerp & 23.03 .1923 & $\mathrm{~F}$ & Skull/skeleton \\
\hline RMCA & $6063 \mathrm{~b}$ & Shinka Boma & Zoo Antwerp & 23.03.1923 & $\mathrm{M}$ & Skull/skeleton \\
\hline RMCA & 9583 & Shinkakassa & Zoo Antwerp & 11.02.1929 & M & Skull/skeleton \\
\hline RMCA & 18313 & Kalamu river & Mesmaekers & 14.07.1948 & M & Skull \\
\hline RMCA & 18314 & Kalamu river & Mesmaekers & 14.07.1948 & $\mathrm{M}$ & Skull \\
\hline RMCA & 18315 & Kalamu river & Mesmaekers & 14.07.1948 & M & Skull \\
\hline RMCA & 18316 & Kalamu river & Mesmaekers & 14.07.1948 & M & Skull \\
\hline RMCA & 20170 & Bas Congo & Maree & 27.11 .1950 & $\mathrm{M}$ & Skull \\
\hline RMCA & 21530 & Boma & Zoo Antwerp & 08.12 .1952 & $\mathrm{~F}$ & Skin/skeleton \\
\hline RMCA & 22930 & Boma & Mesmaekers & 12.05 .1955 & $M$ & Skull \\
\hline RMCA & 31512 & DRC & Zoo Antwerp & 13.09 .1963 & $\mathrm{M}$ & in toto in alcohol \\
\hline RMCA & 35741 & Lukunga & Zoo Antwerp & 13.03.1970 & $\mathrm{M}$ & Skin/skull/skeleton \\
\hline
\end{tabular}

Table 1: Zoo and museum specimen of Trichechus senegalensis from the DRCongo. RMCA: Royal Museum for Central Africa, Brussels, Belgium; ANMH: American Natural History Museum, New York, USA. 
Citation: Laudisoit A, Collet M, Muyaya B, Mauwa C, Ntadi S, et al. (2017) West African Manatee Trichechus senegalensis (LINK, 1795) in the Estuary of the Congo River (Democratic Republic of the Congo): Review and Update. J Biodivers Endanger Species 5: 181. doi: 10.4172/23322543.1000181

Page 6 of 11

ponds due to water level decrease and handed to ICCN wardens $(\mathrm{N}=5)$, animals caught in net and handed to ICCN wardens $(\mathrm{N}=2)$, and animal drowned in fishing net and handed to ICCN wardens $(\mathrm{N}=1)$.

\section{The perception of manatees in local communities}

The manatee is well known in the study area as the "Ngulu ya

\begin{tabular}{|c|c|c|c|}
\hline ID & Dates & Length $(\mathrm{cm})$ & Contour $(\mathrm{cm})$ \\
\hline \multirow[t]{4}{*}{21530} & 20/9/1949 & 176 & 122 \\
\hline & 20/9/1949 & 185 & 133 to 134 \\
\hline & 20/9/1951 & 185 & 134 \\
\hline & 20/9/1952 & 185 & 134 \\
\hline \multirow[t]{12}{*}{35741} & $29 / 10 / 1954$ & 184 & 123 \\
\hline & 29/10/1955 & 188 & 137,5 \\
\hline & $29 / 10 / 1956$ & 203 & 150 \\
\hline & 29/10/1957 & 221 & 154 \\
\hline & 29/10/1958 & 228 & 155 \\
\hline & $29 / 10 / 1959$ & 234 & 155 \\
\hline & $29 / 10 / 1960$ & 238 & 155 \\
\hline & 29/10/1961 & 239 & 156 \\
\hline & 29/10/1962 & 242 & 159 \\
\hline & 29/10/1963 & 246 & 163 \\
\hline & 29/10/1964 & 246 & 164 \\
\hline & 19/9/1969 & 241 & 161 \\
\hline 31512 & $26 / 08 / 1953$ & 200 & 124 \\
\hline
\end{tabular}

Table 2: Measurements sequences of Belgian museum and zoo specimens of Trichechus senegalensis from the estuary of the Congo River, Democratic Republic of the Congo. maza" (literally; the pork of the river) in the respondents 'mother tongue Kikongo. However, none of the local tribes or ethnic groups mentions manatees as totem or myth, legend, song, poem, or taboos. In contrast to other regions, there is no local awareness of the value of the species or its parts (bones, skin, teeth, and ear oil) and their presumed importance in Chinese traditional medicine. The group interviews revealed that $19 \%$ of the respondents $(\mathrm{N}=78)$ consider the manatees as a potential touristic asset because of their status: a rare species, a gift of God, that is only found in Bas-Congo in the DRC.

\section{Distribution of Manatee populations in the Democratic Republic of the Congo}

According to experienced fishermen $(50 \pm 11$ years old, $n=6)$, manatees migrate to the river channels, shallower and quieter waters during high tides and rising water levels in September. They are said to avoid the main Congo stream until December-January. This information is consistent with the records concerning the fluctuations of the Congo River flow that reaches up to $60,000 \mathrm{~m}^{3} / \mathrm{s}$ between October and February, and drops to $30,000 \mathrm{~m}^{3} / \mathrm{s}$ during low water seasons especially in august [26]. Two respondents mentioned that manatee can drown (especially young animals) when water level rises and the strength of the current increases. The respondents also knew that the main territory of manatees in the DRC is situated in the Lukunga River and its network of inland radiating channels which form temporary ponds where females come to whelp from September until December. Two calves have been poached in these channels. The Mateba Island or Cul-de-Boma (S5.89322 E12.88326) near Boma town is reported as

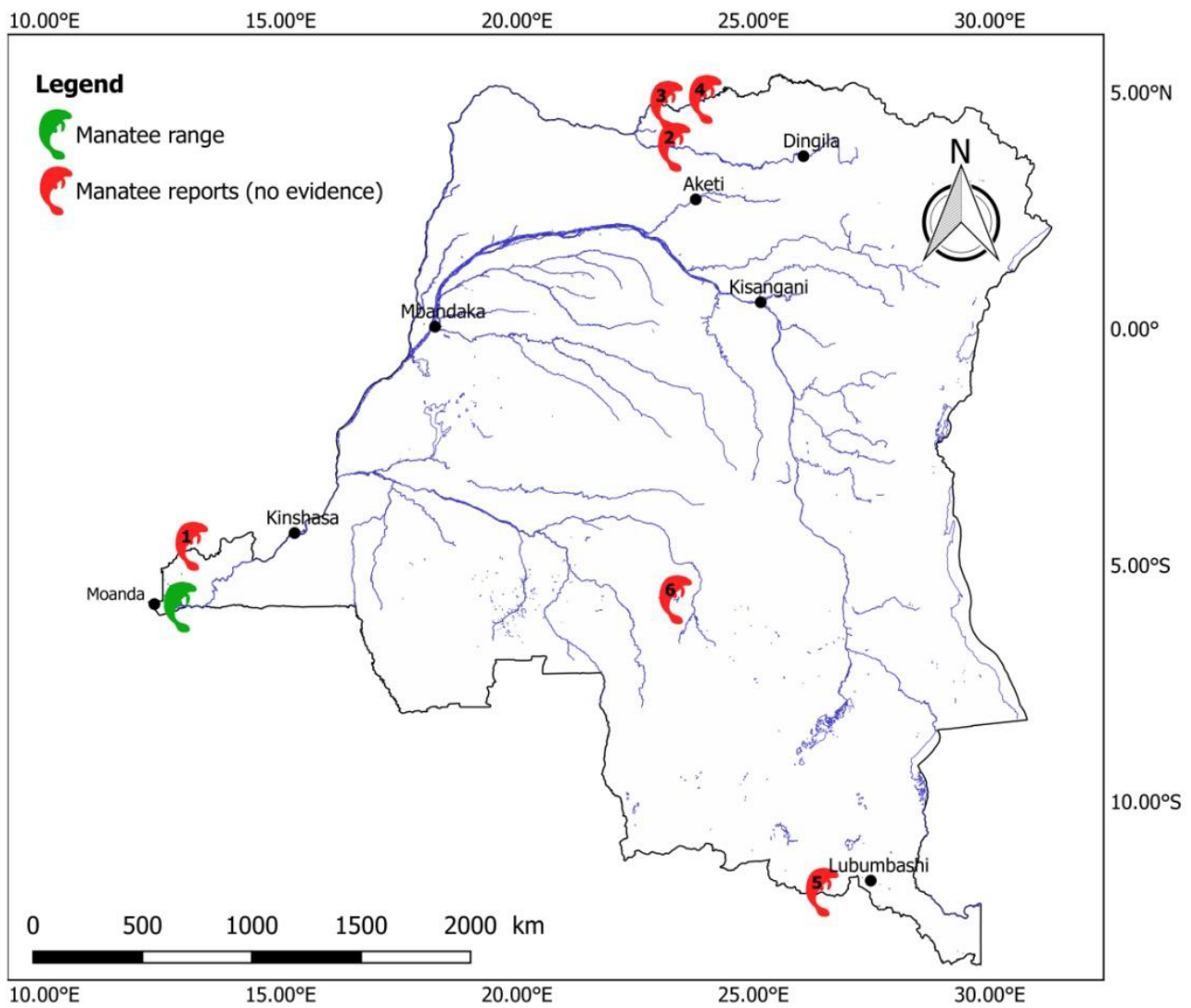

Figure 3: Map showing the observed and hypothetical distribution of Trichechus senegalensis in the Democratic Republic of the Congo. (1) Tshela area, (2) Mbomu River, (3) Uélé River, (4) Chinko River, (5) Lualaba River (upper reaches of the Congo River), and (6) Fwa Lake. 
a site where manatees come to play and mate from September until December. This observation confirms that in times of high waters and increased water flow a diversity of shallow temporary channels develop that are filled with warmer and slowly streaming water.

The presence of two cirripeds species on the skin of some $T$. senegalensis specimens caught or observed in Western Africa [15] clearly indicates there (at least temporary) presence in marine environment. However, during our survey, none of the respondents had ever seen or heard-even from parents or grand-parents-of a manatee caught in the ocean. In order to confirm this fact, pictures of manatees with heavy skin parasites (barnacles) infestation and algae were shown; no villagers reported having seen a similar parasitism in specimens from the Congo River estuary.

\section{Perceived manatee population trend and their ecosystemic role}

The respondents perceived that-in decreasing order of importancethe causes of manatee mortality are water pollution, fishing, illegal hunting, dredging, and diseases. Habitat degradation was never mentioned as a potential threat to the species. Respondents believe that, since 2010, the manatee population size has increased in particular around the Lukunga river area. According to the fishermen and villagers, this fact is not only due to the prohibition of poaching which has existed for over 40 years, when the Régie des Voies Maritimes et fluviales (Office of maritime and river routes) warned villagers not to kill the 'tractors' of the river. The in-depth interviews with experienced fishermen also revealed the perceived local importance of manatees. These fishermen asserted that manatees facilitate their activities by digging into the river bottom of the Congo River, and especially its narrower channels, and that these dredging activities prevent silting. By doing so, the suggest that manatees not only facilitate travelling by dug-out canoes, but that they also create deep, protected holes where large fish can take refuge, or hide to spawn. Therefore, these fishermen reckon that the presence of manatees has a positive effect on their daily fish catch.

Already in 1901, the London International Convention recognized the need to protect African Sirenia. Accordingly, the Congo Free State had included T. senegalensis in the list of animals that can only be killed in small numbers, and only by holders of a license issued by the Governor General. These limitations and bans, all theoretical, have for most of the time been ignored since the independence of the DRC. It seems that the current attitude towards manatee hunting stems from the positive consequence of the strengthened Congolese Nature Conservation Institute (ICCN) surveillance since 2010 and the fact that poaching manatees can yield jail sentences up to 10 years since 2013 .

\section{Perceived manatee diet and grazed vegetation: field observations}

The diet of the manatees is perceived differently by villagers living along the Congo River and its channels. First, people living along the Congo River perceive the water hyacinth (Eichhornia crassipes) as the manatee's main food item. This might stem from the fact that few of the lesser channels are accessible for villagers; hence, their unawareness of the more important diversity of floating and riparian vegetation in these often remote sites. Moreover, the fact that manatees feed on the water hyacinth suggests this must be a relatively recent switch in their diet, as this invasive plant was first reported to occur in the Congo River in 1950 [27].

Fishermen from Boma and Lukunga areas have a different perception on the manatee diet and have detailed knowledge of the main food items. According to them, manatees feed on at least 11 plant species, 6 of which are reported more frequently and in order of decreased observation frequencies-in Kikongo; namely: masese (Echinochloa pyramidalis HITCH. \& CHASE), mbala fuba (Ipomea aquatic FORSSK.), ntuba (Echinochloa sp. P.BEAUV.), kibu (Cyperus papyrus L.), nsamfi or sala (Ludwigia tiberosa RAF.), bitwitwa (floating lettuce Salvinia molesta D.S.MITCH.) and Congo ya sika (water hyacinth, Eichhornia crassipes). It has to be noted that manatees feed both during day and night; and that the reported observations were probably biased towards the period that people are fishing or navigating along the river and channels.

\section{Morphologic characteristics of Congolese manatees}

Between January 2014 and 2015, seven manatees (3 females and 4 males) rescued from poachers or fishermen nets were sexed and measured (Table 2). Rathbun [28] reports that adult T. senegalensis measure 3-4 m and weigh between 363-460 kg. These values are rather similar for Amazonian manatees (up to $3 \mathrm{~m}$ long, and weight below $500 \mathrm{~kg}$ ), that are cited as the smallest Trichechid members [29]. A new born T. senegalensis calf weighs about $30-50 \mathrm{~kg}$ for a length of $30-50 \mathrm{~cm}$ (ratio weight: size $=1: 1$ compared to $1.15-1.20$ for adults). The estimated length of a recently born calf-given by the respondents in two different sites (Kidima S5.82745 E12.90461 and Pont Bangando S5.80786 E12.88497) is between 75 and $80 \mathrm{~cm}$. Information on newborn calves of T. senegalensis is virtually nonexistent; only Dekeyser [21] reported captures of $1.05 \mathrm{~m}$ and $1.04 \mathrm{~m}$ calves [30]. Although this information is continually cited, it should be stressed that these measures are based on only few adults and new born manatees. The skins of 3 specimens (RMCA 53, 110, 111) were measured and were found to be respectively $115 \mathrm{~cm}, 125 \mathrm{~cm}$ and $205 \mathrm{~cm}$ long.

The straight length and weight of two imported zoo specimen were respectively $1.84 \mathrm{~m}$ and $100 \mathrm{~kg}$ (F; RMCA 21530) and $2.46 \mathrm{~m} \mathrm{(M}$ RMCA 35541). Interestingly, skulls and skeletons kept at RMCA do not suggest that those specimens were full grown adults since

Growth cartilage is clearly visible on the epiphysis of their fin bones;

$>$ Cranial bones are not fused.

Our measurements suggest that $T$. senegalensis from the mouth of the Congo River in the DRC-and Angola most resemble the Neotropical species T. inunguis. Based on the growth rate curves and calculated likely-equations parameters of T. inunguis [31], the average length at birth for Amazonian manatees was estimated to approximate $113 \mathrm{~cm}$ (minimum=87 $\mathrm{cm}$ and maximum=152 $\mathrm{cm}$ ) for males calves. This value is consistent with

$>$ The size of male number 2 and male number 4 which were described as juveniles by locals;

$>$ A calf from southern Gabon which was $117 \mathrm{~cm}$ long and weighed $27 \mathrm{~kg}$ when rescued;

$>$ The estimated size of recently born calves reported by interviewed fishermen. Interestingly, the fact that so far only young and sub-adult specimen were caught in the Congo River in DRC (unfused cranial bones) and imported agrees with recent observations and measurements of the specimen rescued in the MMP.

This observation raises the question whether the Congo River 
Citation: Laudisoit A, Collet M, Muyaya B, Mauwa C, Ntadi S, et al. (2017) West African Manatee Trichechus senegalensis (LINK, 1795) in the Estuary of the Congo River (Democratic Republic of the Congo): Review and Update. J Biodivers Endanger Species 5: 181. doi: 10.4172/23322543.1000181

Page 8 of 11

channel network in DRC represents the nursery and/or the refuge of the manatee population of the Congo River? The comparison of the population structure (age pyramid and haplotype) from the most southern population (Cuanza river) and representatives from the Congo river in Angola and DRC would allow to answer this question and may be of prime importance for conservation efforts that would specifically target the protection of gestating females, mothers and calves.

\section{Genetic characteristics of Congolese manatees}

To assess the taxonomic status of the Congolese manatee populations, we compared mitochondrial DNA sequences of Congo River manatees and representatives of the nominal T. senegalensis. The only manatee species for which subspecies have been identified so far is the West Indian manatee T. manatus, with 2 confirmed subspecies; namely the Florida manatee Trichechus manatus latirostris and Antillean or Puerto Rico manatee Trichechus manatus manatus. The substantial degree of genetic differentiation detected between the Florida and Puerto Rico populations is accompanied by corresponding morphological and craniometric distinctions that underpin their taxonomic status as subspecies [3,32,33]. Although several recent studies already included West Indian and Amazonian manatees $[1,5,34,35]$ so far the assayed $T$. senegalensis populations did not include sequences from Congolese populations [36]. Genetic differentiation between inland specimens are close to differentiation between coastal animals taken from Ghana and Senegal (2.5\% divergence) as well as for animals from the nominal subspecies of the West Indian manatee (3.6\% divergence [37].

We based our phylogenetic analysis on a $410 \mathrm{bp}$ fragment of the mitochondrial D-loop included 7 specimens of the Congo River sharing an identical haplotype, all available Trichechid D-loop sequences sequences and a sequence for Dugong dugong as out group. For all tree building methods (Figure 4A and 4B), the Congo River T. senegalensis specimens $(\mathrm{N}=7)$ cluster with the Senegalese manatee populations, in particular to haplotypes Y01, Y02, Y03, Y04 and Y05 from Vianna et al. [25].

While there are no recognized $T$. senegalensis subspecies, the existing genetic information indicates high genetic diversity [25], low nucleotide diversity and the existence of two clades that align geographically [1]. The fact that the 7 Congolese specimens shared a single haplotype may either be due to sampling within a single female matrilineal lineage, or be an indication of low genetic variation among the individuals of this population. However, it is interesting to note that seven of the eight control region haplotypes found in Gabon also only occurred alone in a separate water bodies, which may indicate strong local adaptation and low genetic mixing between neighboring populations [1]. Based on earlier observations, it seems very implausible that manatees would migrate between major lagoons and rivers in Gabon by swimming into the ocean [1]. The same scenario may apply for the Congolese T. senegalensis populations that carry only a single haplotype in our sample. While the limited number of specimens sequenced may lead to an underestimation of the genetic diversity of the Congo River population, the harelip (or cleft of the lip) of a rescued specimens (L4 in Table 3) could be interpreted as an indication of inbreeding in this possibly isolated manatee population (Figure 5).

\section{Threats to Trichechus senegalensis in Democratic Republic of the Congo}

Trade and hunting: West African manatees are directly impactedlocally (and globally)-by capture in fishing nets, hunting and trading as bushmeat. The trade in West African manatee bushmeat is well documented in Gabon and elsewhere in West Africa [9,38], meat and oil is reported to be traded illegally between Chad and Cameroon [9], but no such data exist for the DRC and we were unable to discover information on the present trend in Angola. Between January 2014 and 2015, the MMP rangers helped by informants allowed rescuing 7 specimens, and to arrest 2 manatee poachers with a butchered manatee and to confiscate their special wide mesh net used to target manatees specifically. The importance of Sirenians for the bushmeat market can be inferred from the fact that-according to our interviews-these large mammals can fetch $2 \$ / \mathrm{kg}$ on Congolese bushmeat markets. In a province, the Kongo-Central (formerly Bas-Congo), where the poverty rate reaches $69.8 \%$ with a net monthly income of $16 \$$ and $28 \$$ for women and men respectively [39] selling a large $100 \mathrm{~kg}$ specimen nearly represents one year salary. It was reported to the ICCN team

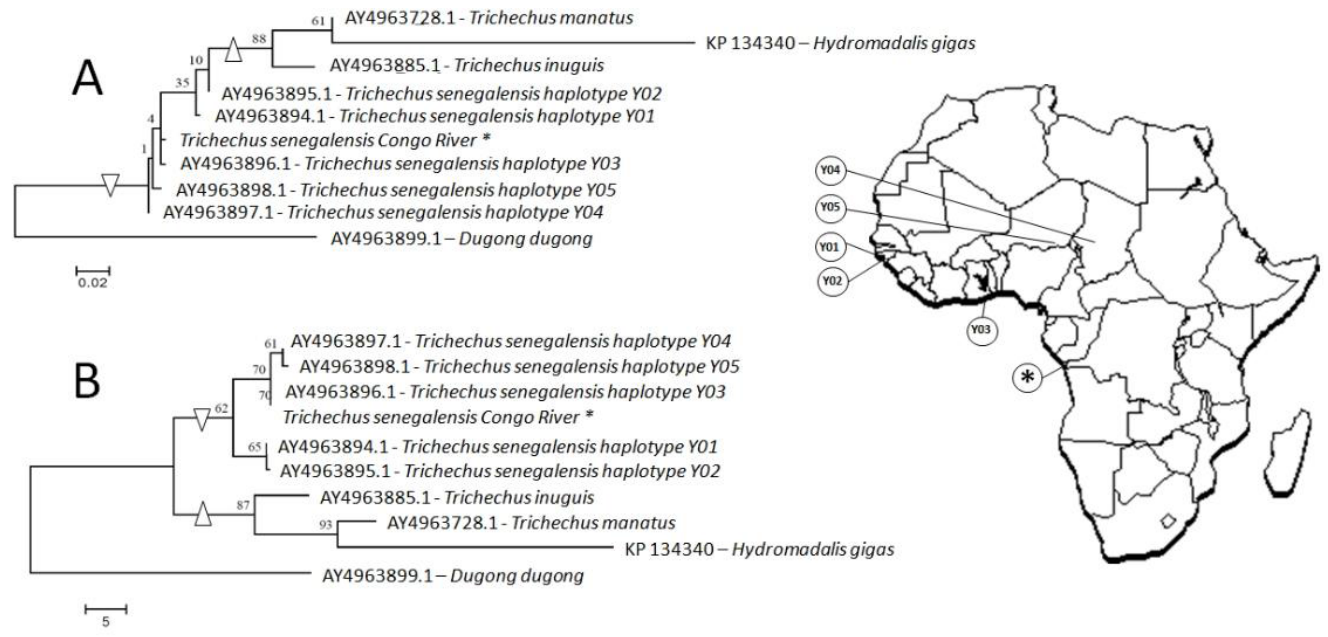

Figure 4: (A and B) Molecular phylogenetic trees obtained using Maximum parsimony and Maximum Likelihood methods group essentially the same haplotypes. Bootstrap support for the obtained clades is rather low throughout these trees that both separate manatees from the new $(\Delta)$ and the old $(\nabla)$ world. The mitochondrial D-loop sequences of the Congolese Trichechus senegalensis population differ only minimally from the available D-loop sequences of West African coastal and inland populations. 
Citation: Laudisoit A, Collet M, Muyaya B, Mauwa C, Ntadi S, et al. (2017) West African Manatee Trichechus senegalensis (LINK, 1795) in the Estuary of the Congo River (Democratic Republic of the Congo): Review and Update. J Biodivers Endanger Species 5: 181. doi: 10.4172/23322543.1000181

Page 9 of 11

\begin{tabular}{|c|c|c|c|c|c|c|c|}
\hline Specimen & L1* & L2* $^{*}$ & L3 & L4 & $\mathbf{L 5}^{*}$ & L6* & $\mathbf{L} 7^{*}$ \\
\hline Sex & M1 & F1 & F2 & M2 & M3 & M4 & F3 \\
\hline Straight length & 192 & 147 & 181 & 112 & 190 & 125 & 176 \\
\hline Snout-Anus & 135 & 107 & 130 & 76 & 128 & 80 & 114 \\
\hline Snout-Urogenital opening & 88 & 96 & 116 & 50 & 84 & 52 & 106 \\
\hline Snout-Ombilicum & 72 & 57 & 67 & 48 & 69 & 47 & 70 \\
\hline Width of flipper & 12 & 10 & 11 & 7.5 & 14 & 9 & 11.5 \\
\hline Length of fluke & 43.3 & 41 & 47 & 34 & 54 & 36.5 & 49 \\
\hline Width of fluke & 43 & 33 & 42 & 26.3 & 48 & 29 & 41 \\
\hline Girth at peduncle & 64.5 & 51 & 63.3 & 44 & 75 & 48 & 67 \\
\hline Girth at anus & 123 & 83 & 102 & 77 & 90 & 99 & 84 \\
\hline Girth at umbilicus & 122 & 103.5 & 126 & 76 & 144 & 89 & 120 \\
\hline Axilliary girth & 101 & 82.5 & 101 & 66 & 113 & 71.5 & 104 \\
\hline
\end{tabular}

Table 3: Measurements of 7 specimens of Trichechus senegalensis from the estuary of the Congo River. L1-L5 measured in January 2015 and L6-L7 in June 2015.

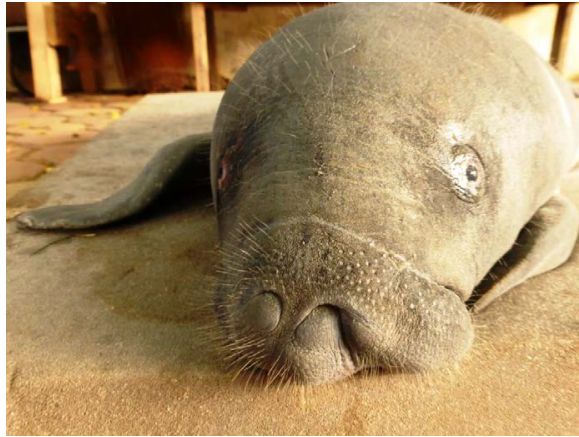

Figure 5: Picture showing the cleftlip of a young Trichechus senegalensis male (L4 in Table 3) rescued in Boma area, estuary of the Congo River, Democratic Republic of the Congo.

that-during the dry season-fresh and smoked manatee meat is sometimes sold on Boma's Fischer (bush meat) market. However, there are no reliable estimates concerning neither the quantity of meat involved nor the geographic origin of the specimen (DRC or Angola?). The proximity with the Angolan border also impedes efficient crossborder control of poached animals in this area since the ICCN team cannot intervene in Angolan waters.

Habitat degradation: West African manatees are also indirectly impacted through the cutting of mangroves (for rice farming, timber, smoking, salt extraction and other purposes) and possibly water pollution with hydrocarbons. However, so far no autopsy (1 performed on a juvenile $T$. senegalensis accidentally drown) has confirmed this hypothesis. Photo interpretation and remote sensing techniques coupled with field observations allowed us to identify five habitat classes (water, anthropized populated areas, savanah and cultivated fields, mangrove and mixed vegetation including gallery and raffia palm forest) in the study area but diachronic comparison with other SPOT or LANDSAT scenes (not presented here) did not allow determining the origin of observed changes. Indeed, the observed changes were subtle at the $30 \mathrm{~m}$ spatial resolution and could have been due to natural yearly or seasonal variations, river water level fluctuations (tide or pluviometry), and anthropic actions. However, operations of the MMP staff associated with Congolese marine officers and ICCN wardens were able to destroy around 500 charcoal ovens (based on mangrove trees carbonization) in the Western part of the MMP since 2012. By doing so, they contributed to the prevention of further mangrove forest erosion near Moanda town ( \pm 40,000 hab.). The dominant activity impacting the mangrove forests by inhabitants of riverine villages is the conversion of forest into vegetable crops such as groundnuts (Arachis hypogea L.), corn (Zea mays L.), cassava (Manihot esculenta CRANTZ.) and pepper (Capsicum frutescens L.) while charcoal is mainly impacting local Rhizophora spp. L. mangrove trees. Despite the MMP efforts, it is still likely-but not quantified-that the already incurred habitat degradation will have a negative impact on the future of the manatee populations of the Congo River estuary. Finally, the project that intends to develop a deep water port at the mouth of the Congo River around the Banana bay may be expected to amplify the demographic pressure on the region's natural resources, as well as increase the boat traffic between Banana bay and Boma. It seems evident that these developments may augment the potential risk of injury for aquatic wildlife, including manatees.

Genetic drift: The risks associated with inbreeding in mammalian populations are a matter of discussion. A classical rule of thumb is that 50 individuals are required to prevent inbreeding in the short term, and that 500 up to $\sim 1000$ individuals are essential to maintain genetic fitness in the long term $[40,41]$. As this numbers appear to be "populationspecific", we should avoid attributing too much importance to these kind of generalisations [41,42]. Not surprisingly, the population size of the T. senegalensis of the Congo River estuary is as poorly documented as it is for most of the other countries where it occurs. The overall population size of the West African manatee is speculated to count less than 10,000 individuals, unevenly spread (linked to the suitable habitat cover area) across 22 countries with captures rate and/or sightings of 250 to 300 annually reported for Cameroun and Guinea Bissau (before 2013). However, it seems likely that manatee populations in some African countries-including the DRC-may not reach the 500 individuals 'threshold. The observed presence of a cleft lipped individual can be regarded as a first hint towards extreme reduction of the Congo manatee population as it might also be a local-anecdotal observation. We suggest that morphometric studies on T. senegalensis from the Congo River and across its range on skulls held museums should be combined with genetic data to test whether $T$. senegalensis consists of several polymorphic conspecific populations, whether these populations may represent operational taxonomical units, and to screen other African manatee populations for the presence of cleft palates. Meanwhile this genetic/genomic data should be used to estimate past and present (effective) population sizes within this study system. Combined, this type of data will be highly relevant to guide future conservation of the species.

\section{Discussion}

We reviewed the available information for the $T$. senegalensis population in the Democratic Republic of the Congo and provided current formal (GIS data point) and informal (interviews/ 
questionnaires) data on this species in its Congolese range. It was once suggested that manatees serve as flagship species for the conservation of wetlands in West Africa [43]. We agree this idea should be revived as the presence of T. senegalensis in the DRC appears to be restricted to the estuary of the Congo River, in a limited mangrove stretch threatened by population growth, human encroachment, and the development of a deepwater port. Since the stability of an ecosystem depends on its original configuration, its disturbance may result in ecological imbalance which in turn could impact the already vulnerable manatee population. An in-depth assessment of the impact and extent of the anthropogenic activities (fishing, hunting, logging, oil extraction, agriculture) on biodiversity in general - such as the natural manatee population of the Congo River estuary-is required to prevent the disappearance of this remarkable aquatic mammal species.

This study attempts to contribute to the development of a sustainable management policy of the manatee throughout its Congolese range. Developing conservation and education programs focusing on the manatee as an enigmatic flagship species of the mangrove-as in Senegalhas thus a clear potential to generate increased awareness which will have positive effects on the ecosystem conservation as a whole. Indeed, in developing countries such as the DRC, efforts to conserve Sirenians and their habitats are currently stalled by data paucity, due to technical and financial constraints to monitor this species. This shortage of data makes it difficult to objectively review the current conservation status of $T$. senegalensis. The recourse to ethnobiological surveys that combine (semi-) structured interviews with participatory, informal approaches may help to overcome this obstacle [44]. Even if villagers and fishermen gave anecdotal information which helped guide our surveys, many uncertainties remain with respect to the status and ecological preferences of $T$. senegalensis in the estuary of the Congo River. Detailed information on many of these "unknowns" (e.g. current population size, gene flow, migration patterns) is of uppermost importance in evaluating the viability of the species (e.g. PVA analysis), which is a crucial aspect in conservation action plans. As such uncertainty on:

$>\quad$ Population size and genetic diversity;

$>$ Temporal migration patterns;

$>$ Current and former distribution range;

$>$ Reproduction areas;

$>\quad$ Fine scale and temporal habitat use need to be addressed.

Based on the conclusions of Mayaka et al. [44] and the findings presented here, we list key measures that are cost-efficient and could be implemented in the short to medium term to help conserve and hopefully restore the T. senegalensis population of the Congo River estuary. Measures that have been applied or attempted elsewhere should be implemented in a near future in the Congo River estuary, in particular: 1) Design a monitoring protocol whereby fishermen can contribute to collect data on manatee presence/absence by geographical sector, season, time of day, and fishing time; identify and focus conservation efforts on key components of manatee habitat systems which include: activity centres, dispersal routes, feeding areas, and sanctuaries such as the Lukunga river and the Cul-de-Boma or Mateba island;2) Continue to ensure law enforcement (i.e. anti-poaching controls, prosecution and deterrent fines) to curb illegal killings and decrease illegal manatee meat trade ; in particular coordinate joint patrols with Angolan nature conservation authorities and research teams, especially around Boma town; 3) Design and implement interactive education programs for school and sensitization campaigns for adults using brochures and meetings; train local communities and/or strengthen their capacities in the sustainable use of mangrove resources and/or promote alternative revenue-generating activities.

Using citizen scientists to gather daily data as suggested above may help determine with more details not only the species distribution according to tiling and season as a first step but also the individuals by developing an image based tool to identify rescued/released individuals. Such a participative approach is a low-cost and efficient method that allows to quickly gathering a great amount of data, to raise consciousness about the importance of the species, and to involve communities in the conservation of their own resources. In addition, understanding the fine scale movement pattern of $T$. senegalensis in the Congo River estuary requires equipping specimens of different age class and sex with a tracking device. The classical ARGOS devices are too conspicuous for taking the risk in the estuary. Obtaining live information on geolocation is challenging for a species that remain submerged most of the day but new miniaturized devices could be modified to respond to the habitat and behaviour of the species such as miniaturized GPS/GPRS waterproof chips. Those two keys will allow identifying the priority areas in terms of $T$. senegalensis monitoring, and will allow the design and implementation of efficient conservation measures for this elusive, threatened and understudied species.

\section{Acknowledgement}

The Congolese Institute for Nature Conservation (ICCN), Mr Louis Mpay Ngueli ICCN ranger and touristic guide in the Marine Mangrove Park, the Congo Basin Biodiversity Conservation (CBBC) association, and PERENCO for logistica and financial support. Sofie Derycke (RBINS), Mark Albert (FWDS, Washington, USA), Théodore Trefond (RMCA, Brussels, Belgium), Dr Pierre Verhaeghe (Veterinary Clinics Ma Campagne, Kinshasa, DR Congo) and Dr Danilo Russo (University of Naples Frederico II, Napoli, Italy) are acknowledged for their valuable scientific advice and support. The IUCN, the Observatoire des Forêts d'Afrique Centrale (OFAC) and WWF Kinshasa are acknowledged for providing spatial data and images used to build the maps.

\section{References}

1. Diagne KL (2015) Trichechus senegalensis. The IUCN Red List of Threatened Species e.T22104A81904980.

2. Luiselli L, Akani GC, Ebere N, Angelici FM, Amori G, et al. (2012) Macrohabitat preferences by the African manatee and crocodiles ecological and conservation implications. Web Ecol 12: 39-48.

3. Domning DP, Hayek LA (1986) Interspecific and Intraspecific morphological variation in manatees (Sirenia: Trichechus). Marine Mammal Science 2:87-144

4. Reynolds JE, Odell DK (1991) Manatees and Dugongs. New York Facts on File Inc 51: 29-30.

5. Rodriguez GAl, Bowen BW, Domning D, Giannoni MAA, Marmontel M, et al. (1998) Phylogeography of the West Indian manatee (Trichechus manatus) how many populations and how many taxa. Mol Ecol 7: 1137-1149.

6. Powell J, Kouadio A (2008) Trichechus senegalensis. In: IUCN 2010. IUCN Red List of Threatened Species.

7. Kouadio A (2007) Conservation Strategy for the West African Manatee. Côte d'Ivoire/Côte d'Ivoire. In: Dodman T, Ndiaye MDD, Sarr K (eds.) Wetlands International, Dakar, Senegal/UNEP-Abidjan Convention, Nairobi.

8. http://sirenian.org/sirenews/33APR2000.html

9. Powell JA (1996) The distribution and biology of the West African manatee (Trichechus senegalensis Link, 1795). United Nations Environment Programme, Regional Seas Programme, Oceans and Coastal Areas, Nairobi, Kenya.

10. Ndour AP (2010) Biologie et génétique du lamantin Ouest Africain Trichechus senegalensis, Sénégal. Université Cheikh Anta Diop, Dakar.

11. Akoi K (1992) Education et sensibilisation des populations pour la conservation du lamantin ouest africain (Trichechus senegalensis) en Côte d'Ivoire. Wildlife Conserv Soc. 
Citation: Laudisoit A, Collet M, Muyaya B, Mauwa C, Ntadi S, et al. (2017) West African Manatee Trichechus senegalensis (LINK, 1795) in the Estuary of the Congo River (Democratic Republic of the Congo): Review and Update. J Biodivers Endanger Species 5: 181. doi: 10.4172/23322543.1000181

Page 11 of 11

12. Silva MA, Araujo A (2001) Distribution and current status of the West African manatee (Trichechus senegalensis) in Guinea-Bissau. Marine Mammal Science 17: 418-424

13. Mbina C (2002) Evaluation and status of manatees (Trichechus senegalensis) of Ogoue bassin in Gabon (first draft)

14. Runge MC, Reed SCA, Langtimm CA, Fonnesbeck CJ (2007) A quantitative threats analysis for the Florida manatee (Trichechus manatus latirostris). U.S. Geological Survey Open-File Report.

15. Beck CA, Forrester DJ (1988) Helminths of the Florida manatee, Trichechus manatus latirostris, with a discussion and summary of the parasites of sirenians. J Parasitol 74: 628- 637.

16. Waltzek TB, Hinojosa CG, Wellehan JFX, Gray GC (2012) Marine Mammal Zoonoses: A Review of Disease Manifestations. Zoonoses and Public Health 59: 521-535.

17. Deutsch CJ, Reid JP, Bonde RK, Easton DE, Kochman HI, et al. (2003) Seasonal movements, migratory behavior, and site fidelity of West Indian manatees along the Atlantic coast of the United States. Wildlife Monogr 151 $1-77$.

18. Dodman T, Ndiaye MDD, Sarr K (2008) Conservation Strategy for the West African Manatee. UNEP, Nairobi, Kenya and Wetlands International Africa Dakar, Senegal.

19. Jefferson TA, Leatherwood S, Webber MA (1993) Marine mammals of the world. FAO species identification guide. Rome, FAO.

20. Marsh H, O'Shea TJ, Reynolds JE (2011) Ecology and conservation of the sirenia: dugongs and manatees. Cambridge University Press, NY, USA.

21. Dekeyser PL (1952) Note sommaire sur la température rectale du lamantin (T. senegalensis Link). Bulletin du Museum National d'Histoire Naturelle 24: 243-246.

22. Perrin WF (2001) Conservation status of the West African Manatee. Sirenews 36: $34-40$

23. Esenowo IK, Akpan UA, Egwali EC (2014) The Behavioural and Morphometric Features of West African Manatee: Trichechus senegalensis in a Semi-Wild Environment. J Biodivers Endangered Species 2:129.

24. Derscheid JM (1926) Les lamantins du Congo. In: Schouteden H (ed.) Revue Zoologique Africaine (Avec Supplément Botanique) 14: 23-31.

25. Vianna JA, Bonde RK, Caballero S, Giraldo JP, Lima RPM, et al. (2006) Phylogeography, phylogeny and hybridization in trichechid sirenians: implications for manatee conservation. Mol Ecol 15: 433-447.

26. Ntadi KS (2015) Contribution de la télédétection optique et radar au suivi du couvert végétal du Parc Marin des Mangroves à Moanda dans la province du Bas Congo. Mémoire de DESS, ERAIFT, Kinshasa.

27. Mbati G, Neuenschwander P (2005) Biological control of three floating water weeds, Eichhornia crassipes, Pistia stratiotes, and Salvinia molesta in the Republic of Congo. Bio Control 50: 635-645.

28. Rathbun GB (1984) Orders and families of recent mammals of the world. In:
Anderson S and Jones JK Jr (eds.) Sirenians. John Wiley and Sons, Inc. NY USA, pp: 537-547.

29. Reynolds JE, Powell JA, Taylor CR (2009) Manatees. Trichechus manatus Trichechus senegalensis and Trichechus inunguis. In: Perrin, Wursig and Thewissen (eds.) Encyclopedia of Marine Mammals. Academic Press, San Diego, pp: 682-691.

30. Husar SL (1978) Trichechus senegalensis. Mammalian Species 89:1-3.

31. Parente VJE, Parente CL, Marmontel M, Silva JC, Sá FB (2010) Growth curve of free-ranging Trichechus inunguis. Biota Neotrop 10.

32. Kellogg M (2008) Sirenian Conservation Genetics and Florida Manatee (Trichechus manatus latirostris) Cytogenetics.

33. Hunter ME, Gomez ANE, Tucker KP, Bonde RK, Powell J, et al. (2010) Low genetic variation and evidence of limited dispersal in the regionally important Belize manatee. Anim Conserv 13: 592-602.

34. Cantanhede AM, Da Silva VM, Farias IP, Hrbek T, Lazzarini SM, et al. (2005) Phylogeography and population genetics of the endangered Amazonian manatee, Trichechus inunguis Natterer, 1883 (Mammalia, Sirenia). Mol Ecol 14: $401-413$

35. Satizábal P, Giannoni MAA, Duchêne S, Herrera CD, Sicchar PCM, et al. (2012) Phylogeography and Sex-Biased Dispersal across Riverine Manatee Populations (Trichechus inunguis and Trichechus manatus) in South America. PLoS ONE 7: e52468.

36. Parr LA (2000) The position of Sirenia within the Subungulates and comparison of intra and interspecific mitochondrial DNA variation in the extant species of manatee. Doctoral Degree Dissertation, Portland State University, Portland Oregon.

37. Parr L, Duffield D, Fain S, Almeida de Silva M (2000) Distribution of Manatee Stocks in West Africa. Sirenews 34

38. Reeves RR, Metzger TD, Kapindi RA (1988) Distribution and exploitation of manatees in Sierra Leone. Oryx 22:75-84.

39. Pnud RDC (2009) Programme des nations unies pour le développement. Unité de lutte contre la pauvreté. Province du Bas Congo. Profil résumé. Pauvreté et conditions de vie des ménages.

40. Franklin R (1980) Evolutionary change in small populations. In Conservation Biology: an Evolutionary-Ecological Perspective, ed. ME Soule, BA Wilcox, Sunderland, MA, pp: 135-150.

41. Frankham R, Ballou J, Briscoe DA (2002) Introduction to conservation genetics Cambridge: Cambridge University Press.

42. Willi Y, Van Buskirk J, Hoffmann AA (2006) Limits to the Adaptive Potential of Small Populations. Annu Rev Ecol Evol Syst 37: 433-458.

43. Dodman T (1999) West African manatee: a flagship species for wetlands Wetlands 8: 18.

44. Mayaka, TB, Awah HC, Ajonina G (2013) Conservation status of manatee (Trichechus senegalensis Link 1795) in Lower Sanaga Basin, Cameroon: An ethnobiological assessment. Trop Conserv Sci 6: 521-538. 